\title{
AN INDIAN SUFI HYMN
}

The following is a metrical translation of a popular Punjabi sacred lyric entitled, "Si Harfi Dholla," i. e. , "A lyric of 30 stanzas in praise of the Beloved." The original Punjabi poem was published at Lahore by Rai Sahib M. Gulab Singh at the Mufid-i-'Am Press in 1317 A. H. (cor. responding to $1899 \mathrm{~A}$. D.) $)^{2}$

The Poet's nom de plume is Talib. The name of his spiritual guide is Chishti. The poem is one of those that are often sung to the accompaniment of music, usually a sarangi, or fiddle.

Unlike the pretentious writings of some world-renowned Persian or Arabic Sufi author, this poem is an unpretentious but thoroughly native, pure Punjabi poem whose popularity and wide acceptance are evidenced not only by its extremely low (nominal) price, but also by the fact that it is used as an early morning hymn by street singers who go about singing such songs, partly as religious worship and partly with the object of receiving alms. This use of the poem by street singers was a great help to the present translator just before his acceptance of Christianity, and also in the early years after his baptism when he lived in the very heart of the city of Lahore.

The poem may be regarded as typical of Sufi literature in several ways: (a) Its three stages of transition from an all-pervading or pantheistic idea of God to His incarnation in the Prophet, and later in the person of the Spiritual Guide from whom the Sufi disciple receives direct guidance and illumination. Usually, however, the transition of thought is supposed to be in the reverse order, so that the pantheistic stage (viz, Faná-

"Sir Harf" (literally "of, or pertaining to, the thirty letters of the alphabet"), is song or poem consisting of thirty stanzas, each stanza beginning with one of the thirty letters of the alphabet "Dholla" is "the Beloved."

${ }^{2}$ First Edition, 10,000 copies. Size, 8 amall pages. Price, one pice. 
fi-llah) succeeds the stages of incarnation (viz. Fanáfi-sh-shaikh and Faná-fir-rasil). (b) Also, with regard to its language, the disciple appears as a woman, a wife, or a bride. The spiritual guide and the Prophet, and ultimately God, figure as a bridegroom or husband. The disciple's constant longing is for the mystic union typified by the union of the bride and bridegroom. This conception prevails throughout oriental, particularly Indian, mysticism, whether Mohammedan, Sikh or Hindu. Compare with this the Old Testament conception of God as the husband of His people, Israel, particularly in the prophets Isaiah and Hosea. Compare also the language and thought of the Song of Solomon. In the New Testament, John the Baptist called himself the friend of the Bridegroom, a figure which Jesus Himself adopted in several instances, with reference to His mission on earth. And in the Epistles of St. Paul and the Book of Revelation the Church is called the Bride of Christ or of the Lamb.

This poem, like many others of its kind, bears out the widespread and thoroughly assimilated character of the influence of Sufism, not only on Moslem but also on non-Moslem thought and religious practice in India. Consider, for instance, the very wide influence exercised by the Kaffis, or Hymns of the great Sufi poet of the Punjab, Bullheshah, of sacred memory, who may well be called "the Hafiz of the Land of Five Rivers." Or, since the Punjab is the heart of Moslem India, he may truly be regarded as "the Hafiz of Moslem India."

We notice this same deep Sufi strain in the sayings of Guru Nanak, the founder of the Sikh religion, and of the great Punjabi saint, Kabir Bhagat, from whom the sect of Kabir Panthis takes its name. ${ }^{3}$ We hope later to give metrical translations of some of the best known of these other Hindustani hymns.

For the Christian evangelist this hymn and others of the same kind will be helpful in showing the close affinity of Moslem Sufism to the message of the Gospel

See the English translations from Kabir by Rer. Abmad Shab of the S. P. G. Mission, Hamirpur, and by Sir Rabindranatb Tagore. 
of Jesus Christ. For instance, the present hymn may be taken as a good illustration of the yearning of the Moslem heart for the incarnate God-Man in Islam. The most remarkable feature of Moslem mysticism is that it seeks perfection of life and character, through passionate devotion to a holy person, imagined or idealised. This fact should exercise the reflex influence of creating and increasing a passionate devotion to the person of Christ in a Christian devotee who attempts to win souls for his Master, even such a passion as St. Paul possessed, which was the secret of his success in evangelistic work.

We are fortunate that such a rare, poetical gift as that possessed by the one who has versified the present hymn is being brought to the service of Sufi hymnody, thus enabling the reader to get the beauty and sentiment of the original poetry, as far as it is possible to do so. It may be mentioned that owing to ambiguity of expression or misprint the translator was obliged to give a more or less doubtful translation of 3 out of 120 lines of this poem, viz, the last lines, in each case, of the I 2 th, 2oth and 23 rd stanzas.

It will help the reader if he keeps in mind the four divisions of the poem which we suggest below.

Part I. Stanzas I to 6. Pantheistic.

Part II. Stanzas 7 to 15 . Divine Incarnation in the person of the Prophet.

Part III. Stanzas 16 to 25. Divine Incarnation in the person of the Spiritual Guide as representative of God through the Prophet.

Part IV. Stanzas 26 to 29. A description of the meeting, the spiritual or mystic union, with the Beloved.

(Stanza 30 is the concluding stanza.)

R. S. D.

NOTE ON THE ENGLISH TRANSLATION

In rendering this hymn into English verse our endeavor has been to approximate the metre, as well as

- One of the well-known doctrines of Sufism is expresced thus: "My Spiritual Guide may be weak like atrar, but my faith is enough." ("Pir-imen Kharart I'tiqed-i man bas ast.") 
to convey the meaning and catch the spirit, of the original. We have also retained the rhyming sequence of the Punjabi in which the same rhyme obtains throughout each quatrain. For purposes of comparison we give the transliteration and a literal translation of the first verse:

Alif $A$ Mian Dholla tere man wieh dere

Chhaddo watan durádá, Kol wasso mere Aprä watan sunáwen sânún sháh ragon nere

Akhin dissen náhín, kahe páe jhere.

$\mathrm{O}$, come, Beloved, Thy habitation is in the soul.

Forsake the distant home and reside near me.

Thou sayest, "Our abode is nearer than the artery of the neck;"

Yet thou art invisible to these eyes. What vexation hast Thou created!

H. A. W.

PART I.

Pantheistic

I

Come, Love, within the soul Thy dwellng-place doth lie.

Thy distant home desert, and to my fond heart fly!

Thou sayest Thou dost bide than the neck vein more nigh;

Yet, vexing one, Thy form is veiled before mine eye.

2.

O, Love, deceive no morel Thy fickle words forsakel Without us and within Thy dwelling Thou dost take. My heart, with wiles bewitched, a captive Thou dost make:

Then into words of scorn Thy mocking accents break.

3.

Oh, Love, for all our woes no pity hast Thou shown;

\footnotetext{
- This line embodies the well-known sentence of the Qur'an, "We (God) are closer to him (man) than his neek rein." (L, 13, b). (Nahns aqrabu min habl-ib. warid.) Tennyson's lines in "The Higher Pantbeism," echo this thought:

"Speak to Him, Thou, for He hears, and Spirit with Spirit can meet, closer is He than breathing. and nearer than bands and feet."
} 
Exiled from Home, to pine in far-off realms alone, Through Thy false deed, Who once had made our souls Thine own.

In this strange land, alas, no peace my heart hath known.

Thou only art; all else is unreality.

Why press this vain debate if one or separate we?

Since, when Thy face is shown, my sighs Thy grief must be,

And in my prayers for death, my tears are tears of Thee. $^{7}$

$$
5 .
$$

I sleep, and at my side Love sinks in slumber deep:

When first my eyes unclose, He rouses, too, from sleep. I Laugh, He shouts for joy; His tears fall when I weep : ${ }^{8}$

Yet bargains $\mathrm{He}$, nor cares my plighted hours to keep.

6.

None knows my state save Love; for no one else 'twere meet.

I sacrifice my all, an offering at Love's feet.

Each moment yearns my heart its guileless Love to greet :

Unless Love quickly come, this heart must cease to beat.

\section{PART II.}

Divine Incarnation in the Person of the Prophet Mohammed

7.

'Twas told that the Beloved to holy Mecca came:

That never man should know $\mathrm{He}$ chose Mohammed's name.

\footnotetext{
- This quartain introduces the Suf belief in the pre-existence of the soul. Exile from Home represents separation from the Beloved at birth. In its new life the soul at this stage seems to feel, with Francis Thompson, "in no strange land."

This conception of the entire oneness of the Belored and the loved one, in the latter's grief, is beautifully expressed, with recard to human love only, in the closing lines of Mrs. Browning's sixth "Sonnet from the Portugueae": " . . . and when I sue God for myself, He bears that name of thine. And sees within my eyes the tears of two."

- One is reminded of St. Paul's injunction in Romans 12-15, "Rejoice with those who rejoice, and weep with those who weep."
} 
Medina, now, His home: and Talib's ${ }^{9}$ fond lips frame Prayers for "God's peace" on $\mathrm{Him},{ }^{10}$ and His high service claim.

\section{8. ${ }^{11}$}

A gift I crave whose sight sweet thoughts of Thee shall start;

With ring from Thy dear hand, or necklace, Thou must part.

In Hindustan, my home; Thou in Medina art.

Slain by Thy love, what sins had soiled my hapless heart?

9.

By telling o'er Thy name each passing hour I grace.

Leave town and vale and make my heart Thy restingplace.

Love reigns the Lord of all; $\mathrm{His,} \mathrm{earth} \mathrm{and} \mathrm{sky} \mathrm{and}$ space.

Since Thou hast made me Thine, whom else should I embrace?

IO.

If e'er my lips, unsealed, Thy mystery reveal, ${ }^{12}$

From mighty rivers' depths great flames of fire will steal,

Blood from God's throne will rain, the stars will earthward reel.

Ah, Love, what streams can cool when these hot fires I feel ? ?3 $^{3}$

II.

My years of youth were spent in doleful tears and sighs.

- "Talib," meaning "a seeker" on the Suf's Path, is the nom de plume of the poet.

1" The words translated "God's peace," or blessing." or "benediction," here and in stanzas 27, 28 and 29, stand for the Arabic phrase, "Salli 'Ald", which habitually follow" Yohammed's aame in Moslem writings. It is an abbreviation for "Sallallokm 'oloihi wa sallam, of which the meaning is, "May God's blessing and peace, be upon bim!"

11 From this stanza onward the disciple throughout speaks of himself as a woman, a bride, a wife, and uses the feminine gender for bimself, and tbe massuline for the Divine Belored.

12 This refers to the esoterie truth of the Sufis, supposed to have originated with Mobammed in the Qur'an, to which the Sufi's lips must ever remain sealed.

10 Compare Song of Soicmion 8:7, "Many waters cannot quench lore, neither can floods drown it." 
Now, to my agéd heart, Love's wingéd arrow flies. Bring hither my Beloved, the darling of mine eyes. Talib's true love from heart as well as tongue doth rise.

I 2.

My artless Love goes by nor casts on me His eyes. Heedless, $\mathrm{He}$ passes by; counsel $\mathrm{Him}, \mathrm{O}$, ye wisel Medina, now, I seek; there my sole refuge lies. $\mathrm{O}$, Talib, plead thy love, till from His course He hies.

I3.

Beloved, my heart now yearns to see Medina fair, ${ }^{14}$ All hidden grief and pain to lay before Thee there. Long years have sped since Love left me to lone despair. All men, O Talib, now toward Thee some malice bear. ${ }^{15}$

14.

Apart from the Beloved, no comfort can I gain. Should one Love's kalima ${ }^{16}$ read, these inward fires might wane.

Remembering Love my lifeless heart revives again. $O$, let Love learn, at last, my piteous cries of pain!

I5.

Thou who my surety ${ }^{17}$ art, O Love, stir not away. Summon me to Thyself, and share my grief, I pray. Secure my pardon, Love, for I have gone astray. To my dead soul give life, and sinless I shall stay.

\section{PART III}

Divine Incarnation in the Person of the Spiritual Guide 16.

Mount Sinai's ${ }^{18}$ lofty height my Love hath put to shame.

\footnotetext{
"It It will be noted that the Sufi's eyes turn not to the Ka'ba at Meces but to Mohammed's tomb at Medina.

whe oriental attitude toward the lover-of either God or man-is quite the opposite of that represented by the Wstern proverb, "All the world loves e lover." The Paalms are full of this enmity of man toward the true lover of God. See also Stanxa 23.

10 The kalima is Mohammed's prescribed Confession of Faith, viz, "There is no sod but God and Mohammed is His Prophet"

"The word "sdmin" is equivalent to a "subatitute" which resembles the Christian ides of vicarious atonement.

In The mountain-top where Moses met God. See Exodus, chap. 19, the Qur'an XXVIII, 44, and otber pasages.
} 
Mounting the throne on high, all-holy God, His name. To tread Medina's streets, as the Beloved, $\mathrm{He}$ came; Now, guiding on the Path, as Chishti, ${ }^{19}$ spreads His fame.

\section{7.}

Inside and out my Love holds His high Sovereignty: In every place He dwells, the First and Last ${ }^{20}$ is He. Save only the Beloved, none other can there be. I live but by His life, Love's own eternally.

18.

From the great Presence sought, Thy bounteous Love I own.

Afar or near, $O$ Love, I see but Thee alone.

All from Thy light have come-no other source have known. ${ }^{21}$

Send pardon from Thyself, nor bid my steps begone.

ig.

Never to know my Love were no man's mournful fate. To her ${ }^{22}$ who is Love's bride my life I consecrate.

For her whom Love hath called, with welcome all would wait.

That Love mine arm would hold, my longing passionate.

20.

Stricken to deàth, I lie, crushed by Thy beauty's wave. In Thy love's ocean vast my soul hath found its grave. In every town men's tongues for Thee their tribute save. To Thee our lives we yield: to see Thy face we crave.

2 I.

This daily task to do, of old my destinyThat I His praise proclaim, whene'er Love summons me.

Whe word "Chishti" relates to a Sufi order founded by nd Din Chishti. India'a moat celebrated Mohammedan saint. He wa a pupil of Abdul gadir. Jiluni. His tomb at Ajmere takes precedence over all others in Indis among saint-worshipping Moslems, and is also visited by thousands of Hindu pilgrims. Here Chishti tando for the name of the Poet's Spiritual Guide.

* Compare Revelation 22:13, "I am the Alphn and the Omega, the first and the last, the beginning and the end.

a Compare John 1:3, "All things were made by Him, and without Him was not anything made that was made."

$n$ The reference is to other brides or disciples of the Master. See note on Stanza 8. 
O, friends, I am consumed; Love's form I cannot see. My Love hath learned to work with what strange witchery!

22.

Who, from the path of Love, my steps shall turn aside ? $^{28}$ If Love desire, my life to $\mathrm{Him}$ would I confide.

Love will not faithless be; my trust hath time defied. Since Love hath held mine arm, with me He must abide.

23.

Love, I am slain, whom men with gibes and taunts assail.

My heart Medina craves, for justice there to wail.

Come, O, my Love, behold, I have removed my veil, My witness thus to add to Thy dear beauty's tale.

\section{4 .}

In the Belovéd's way, friends, I am lost to sight. Then lest $I$ be not found, let all in search unite! This very Love, the thief--O, seize His arm with might! A secker after Love, know me, by day and night.

"Negation's" medicine, 24 Love, for mine eyes was brought;

And now, save only Love, I can distinguish naught.

Love's citadel He showed, with every splendor fraught. Love, I am lost indeed what magic hast Thou wrought?

\section{PART IV}

The Mystical Union with the Beloved.

26

Love, I would die for Thee, most ravishing Thy grace. Bring news, O friends, from whence comes the Beloved's face.

My soul with joy grows faint, and faster, my heart's pace.

"Compare Romans 8:35 "Who shall separate us from the love of Cbrist?"

"Naf Isbdt." "Negation and afirmation," an expression used to describe the bighest dhikr or repetition of the sacred "Kalima," "La Ilaha Illalloh." The first part, "La llaka," "There is no (false) cod," is the negation or the rejection of all false gods. Hence "negation" is here equivalent 10 -complete absorption in the thought of the Beloved. 
What if, this morn, should come Love's step and His embracel

27.

My necklace is God's praise, wherewith I am arrayed.

My ear-rings are the prayer, "God's peace"20 my lips have prayed.

Love, on my heart, for gems, longing for God hath laid. The nuptial bed I mount, invoking Chishti's aid.

\section{8}

The heavenly lightnings flash, and blazing fountains spout.

With Sinai's ${ }^{28}$ splendor clothed, my glory shines about. Love, entering at last, "My follower," calls out.

Beings of light and fire and earth, ${ }^{27}$ "God's blessing" shout.

29.

To meet Love, as He comes, with bended head I go, "God's benediction" ask, and at Love's feet bow low This hand-maid's ministry, unworthy, all must know. Talib, Thy slave to keep-this boon, O Love, bestow.

30.

How bountifully, Love, Thy gracious mercies fall. Ever Thy faith I own, Thy kalima ${ }^{28}$ recall;

Ever at Thy blest tomb, I sacrifice my all; Ever on Chishti, Guide, with grateful spirit, call. R. Siraj Ud DiN. H. A. Walter.

Lahore, India.

- See note on stanza 7.

* See note on stanea 16.

nThat is, angels, jinn (zenii), and men, who. Moslems beliere, are created, respectively, out of light, fire and clay. See Qur'an XV, 26, 27, and L.V, 13, 14.

- See note on atenra 14. 